\title{
POLÍTICA HABITACIONAL E LOCAÇÃO SOCIAL EM SALVADOR
}

\author{
Nelson Baltrusis* \\ Laila Nazem Mourad ${ }^{* *}$
}

\begin{abstract}
Este artigo tem como objetivo analisar o mercado imobiliário de locação em Salvador. Num primeiro momento, caracterizaremos o problema habitacional em Salvador, para o que nos apoiaremos nas diretrizes e ações previstas no Plano Municipal de Habitação de Interesse Social (PMHIS). Em seguida, trataremos das políticas implantadas pelos governos do estado e federal, destacando a experiência do Programa de Arrendamento Residencial (PAR) e incorporando algumas considerações sobre o Programa Minha Casa, Minha Vida. Também será abordada a questão do mercado de locação em Salvador a partir do perfil de moradores e da dinâmica do mercado.

PALAVRAS-CHAVE: Aluguel social. Política de habitação. Instrumentos de planeamento urbano.
\end{abstract}

\section{INTRODUÇÃO}

Na Bahia, de acordo com o IBGE (2010), o déficit total de unidades habitacionais está em torno de 510.577, das quais 141.000 na Região Metropolitana de Salvador. A pressão exercida por esse déficit é responsável pelo encarecimento do preço do solo urbanizado, fazendo com que a população pobre e os agentes públicos (responsáveis por suprir esse déficit) disputem o mesmo espaço com agentes do mercado imobiliário. Com o intuito de garantir o acesso à terra urbanizada e bem localizada para a produção de habitação social, o Estatuto da Cidade, referendando a Constituição

\footnotetext{
* Doutor em Arquitetura e Urbanismo. Professor adjunto do Programa de Pós-graduação em Planejamento Territorial da Universidade Católica do Salvador. Professor da Universidade Católica do Salvador. Pesquisador colaborador da Pontifícia Universidade Católica de São Paulo, Instituto de Estudos, Formação e Assessoria em Políticas Sociais.

Av. Cardeal da Silva. 205. Cep: 40231902. FederaçãoSalvador - Bahia - Brasil.nbaltrusis@hotmail.com

* * Doutora em Arquitetura e Urbanismo. Bolsista de pósdoutorado PNPD-Capes. Membro do grupo de pesquisa Lugar Comum.

Rua Caetano Moura, 121, Sala de Pesquisa LUGAR COMUM. Cep: 40140-310. Ondina - Salvador - Bahia - Brasil.mourad.laila7@gmail.com
}

Federal, reforçou a tese de que a terra precisa cumprir uma função social.

De acordo com o IBGE (2010), 40,8\% do déficit habitacional nacional correspondem ao gasto excessivo com aluguel. Em Salvador, esse déficit é de 46,5\%, e isso significa que 53.253 domicílios, ou 31,5\% dos imóveis residenciais soteropolitanos destinados à locação fazem parte do déficit.

Diante desse quadro, parece-nos importante tecer alguns comentários a respeito da ausência de programas voltados para a produção de locação social, apesar de haver legislação que trata da questão e algumas experiências, principalmente relacionadas aos programas de Bolsa-aluguel, do Programa de Arrendamento Residencial (PAR), que foi implantado pelo Governo Federal através da Caixa Econômica Federal (CEF), e do Programa de Locação Social da Prefeitura Municipal de São Paulo (PMSP).

Algumas questões nos parecem importantes. Uma delas é saber o porquê, diante de tanta regulamentação, o local destinado à produção de unidades ou conjuntos voltados para o aluguel social não está demarcado. Decerto, poderíamos 
dizer que habitações de aluguel para a baixa renda estariam em Zonas Especiais de Interesse Social (Zeis). ${ }^{1}$ Mas, então, qual seria a percentagem de áreas destinadas a esse uso? Quais os benefícios para a cidade, o morador e o empreendedor? Como gerir os conflitos oriundos dos vários tipos e usos na cidade? Quem se responsabilizaria pela manutenção do imóvel ou do conjunto? Como isso seria feito? Que parâmetros devem ser utilizados para se edificar um empreendimento voltado para locação de aluguel? Porque não se utiliza o estoque de imóveis vazios em áreas centrais, para atender a essa demanda? Essas são algumas questões que vêm à tona quando discutimos o assunto. Não pretendemos, neste artigo, dar conta de tais questões, muito menos esgotar o tema.

Este texto procura tratar o problema da habitação do ponto de vista das políticas de locação social, ou da falta delas, elegendo o município de Salvador. Busca-se verificar a abordagem da legislação de uso do solo e do Plano Diretor sobre a questão. Num primeiro momento, caracterizaremos o problema habitacional em Salvador, com apoio nas diretrizes e ações previstas no Plano Municipal de Habitação de Interesse Social (PMHIS). Em seguida, trataremos das políticas implantadas pelos governos do estado e federal, destacando a experiência do Programa de Arrendamento Residencial (PAR) e incorporando algumas considerações sobre o Programa Minha Casa, Minha

Tabela 1 - Evolução da população, Brasil, Bahia e Salvador 1940-2012

Fonte: IBGE 1940-2010

${ }^{1} \mathrm{O}$ instituto das Zonas Especiais de Interesse Social (Zeis) é um instrumento urbanístico que se apoiou em experiências locais (Recife, Diadema, Salvador e etc.). As Zeissão porções do território destinadas, prioritariamente, à recuperação urbanística, à regularização fundiária e à produção de habitação social, incluindo a recuperação de imóveis degradados, a provisão de equipamentos sociais e culturais, espaços públicos, serviços e comércio de proximidade. Vários municípios demarcaram, em seus planos diretores, ou em sua legislação de uso do solo, glebas e áreas vazias como Zeis, com o intuito de produzir habitações de interesse social. A esse respeito, ver Mourad (2000)
Vida. Também será abordada a questão do mercado de locação em Salvador, através do perfil de moradores e da dinâmica do mercado.

\section{CARACTERIZANDO O PROBLEMA}

Salvador, capital do estado da Bahia, se notabiliza por sua bela orla marítima, pela desigualdade social e por ser o terceiro município mais populoso do Brasil, com 2.675.656 habitantes, residindo em 858.887 domicílios (IBGE, 2010). Entre 1940 e 2012, o incremento populacional foi de mais de $900 \%$, e transformou uma cidade de 290.000 moradores, em 1940, numa metrópole com mais de 2,5 milhões de habitantes em 2010. Cerca de 30\% do total de seus domicílios são classificados como aglomerados subnormais. O território soteropolitano é marcado por uma ocupação da elite, ligada às famílias tradicionais, e uma pequena classe média, que está cercada por uma população de pobres.

De acordo com dados do Ministério das Cidades, em 2011, o déficit habitacional em Salvador foi estimado em 114.524 unidades, o que correspondia a 13,3\% do parque residencial da cidade. Já os domicílios vazios ou sem uso correspondiam a 12,5\%. Grosso modo, poder-se-ia suprir a falta de moradias utilizando os imóveis vazios.

$\mathrm{O}$ último censo aponta para o fato de que

\begin{tabular}{lcccccccc}
\hline & 1940 & $\mathbf{1 9 5 0}$ & $\mathbf{1 9 6 0}$ & $\mathbf{1 9 7 0}$ & $\mathbf{1 9 8 0}$ & $\mathbf{1 9 9 1}$ & $\mathbf{2 0 0 0}$ & $\mathbf{2 0 1 0}$ \\
\hline Brasil & 41.236 .315 & 51.944 .397 & 70.992 .343 & 94.508 .583 & 121.150 .573 & 146.917 .459 & 169.590 .693 & 190.755 .799 \\
\hline Bahia & 3.918 .112 & 4.834 .575 & 5.990 .605 & 7.583 .140 & 9.597 .393 & 11.855 .157 & 13.066 .910 & 14.016 .906 \\
\hline Salvador & 290.443 & 417.235 & 655.735 & 1.027 .142 & 1.531 .242 & 2.072 .058 & 2.440 .828 & 2.675 .656 \\
\hline
\end{tabular}

20\% das residências em Salvador são utilizadas para locação. Essa porcentagem reflete uma recuperação em relação à década anterior, quando os domicílios de aluguel chegaram ao mais baixo índice (15,46\%) desde a década de 1940.

Como podemos observar no Gráfico 1, entre 1940 e 2000, os domicílios residenciais desti- 
nados à locação vêm diminuindo em relação aos domicílios próprios permanentes. Na década de 1940-50, eles representavam 58,3\% do parque residencial; já na década seguinte, essa percentagem recuou para 52,4\%. Em 1970, os domicílios locados representavam $38,6 \%$, na década seguinte, caem para 34,8\%. Entre 1980 e 1991, observase uma nova queda, chegando a 19,4\%. De 1991 a 2000 , observa-se uma queda de $8 \%$. No censo de 2010 , verifica-se um incremento de $30 \%$ em relação à década anterior.

Gráfico 1 - Porcentagem dos domicílios alugados

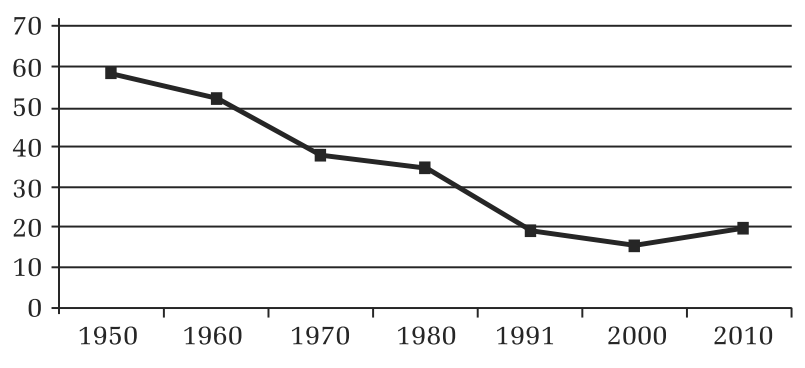

Fonte: IBGE, 1950, 1960, 1970, 1980, 1991, 2000 e 2010

\section{A construção da ideologia da casa própria}

Araújo (2010) destaca que, na década de 1930, o mercado em Salvador já se demonstrava dinâmico, tanto em relação à locação de quartos e casas para os pobres, quanto à venda de casas para a classe média que estava surgindo. No entanto, a questão da precariedade residencial já se fazia presente. Essa relação da moradia com o espaço da cidade deve ser compreendida dentro de um contexto histórico, e pode ser entendida como uma consequência direta do período de escravidão. Suas particularidades refletem as condições de vida e as atividades econômicas desenvolvidas pelos escravos e depois ex-escravos. Estima-se que, entre 1943 e $1944,75 \%$ da população se alojavam em mocambos, favelas e cortiços (SEHAB, 2007, p. 77).

Um estudo realizado pelo Escritório de Planejamento Urbano da Cidade de Salvador (Epucs) constatou que, em 1943, 72,53\% dos imóveis de aluguel eram locados por um valor abaixo dos
Cr\$100,00 (cem cruzeiros), e basicamente se constituíam de cortiços, residências em avenidas centrais e casebres na periferia. De acordo com Araújo (2010, p. 105), "o projeto idealizou manchas de moradia de baixo tipo econômico próximas a áreas residenciais valorizadas".

Nessa mesma década (1940), iniciou-se um processo massivo de ocupação do solo urbano. A cidade passou a receber um fluxo muito grande de migrantes "formados por trabalhadores rurais dispensados pela decadente cultura açucareira do

Recôncavo e a estabilização da cultura do cacau no sul da Bahia” (Villagra; Oliveira, 2006, p. 32).

Esse fluxo migratório afetou de forma significativa a estrutura fundiária e imobiliária, promovendo ocupações irregulares de áreas livres. De acordo com Gordilho-Souza, até a década de 1940, havia um relativo equilíbrio entre oferta e demanda, apoiado num "sistema de aforamento e arrendamento de terras e aluguéis de casas, principalmente para os estratos sociais de média e baixa renda" (Gordilho-Souza, 2000, p. 112). Esse incremento populacional, aliado à legislação que congelou os aluguéis em 1940, ajudou a agravar tal quadro, porque mais da metade do parque residencial era destinado à locação, contribuindo para que houvesse uma "demanda por novas habitações envolvendo praticamente todos os estratos sociais e da inelasticidade da oferta de terra" (Gordilho-Souza, 2000, p. 112). Instaurou-se, então,

... [uma] crise habitacional de grandes proporções que resultou em implicações diretas na valorização do solo urbano e no aumento do valor dos aluguéis, que se tornariam inacessíveis também para a parcela da população que tinha nessa alternativa a solução para o seu problema de moradia. Podemos dizer que essa crise foi agravada pela concentração da propriedade fundiária e pelo comprometimento com institutos como a enfiteuse, ${ }^{2}$ herança da tradição jurídica portuguesa introduzida com a colonização, que tornara perpétuos os direitos de posse sobre terrenos de propriedade do Município, limitando a ação do Poder Público à abertura de novas áreas para habitação popular (Sedham, 2009, p. 44).

${ }^{2}$ Enfiteuse: o mesmo que aforamento, direito real alienável e transmissível aos herdeiros, e que confere a alguém o pleno gozo do imóvel mediante a obrigação de não deteriorá-lo e de pagar um foro anual, em numerário ou em frutos, ao proprietário. 
Carvalho e Pereira (2006, p. 138) reforçam essa tese. Segundo eles, a partir de 1940

... [o acesso] à moradia da população de baixa renda esteve vinculado a processos de parcelamento improvisado e autoconstrução, envolvendo as invasões, os loteamentos clandestinos e outras formas de moradia deficientes de atributos de habitabilidade, que constituem a ocupação informal na área urbana. Informal, no sentido de que se constituíram à revelia dos parâmetros urbanísticos estabelecidos e cresceram fora das regras de segurança e conforto estabelecidos pelo poder público para edificações e parcelamento.

Com isso, um processo de urbanização excludente consolidou um padrão de desigualdade socioespacial semelhante ao de outras grandes cidades brasileiras. A ineficácia das políticas de provisão para atender à demanda das camadas populares e a incapacidade de o mercado produzir unidades voltadas para a baixa renda, bem como a não aplicação plena dos mecanismos de controle e uso do solo, podem ser apontados como responsáveis por esse quadro (Baltrusis, 2000). Via de regra, os investimentos e a legislação de uso, controle e gestão do solo urbano elegeram e privilegiaram investimentos em determinadas áreas, que foram apropriadas pelo mercado, particularmente pelo setor hoteleiro, em detrimento das localizações dos mais pobres.

As mudanças na estrutura da capital baiana também contribuíram como fator de atração do capital imobiliário. Carvalho e Pereira destacam que a cidade de Salvador se modificava,

[...] em função de vários fatores, como a reestruturação do centro da cidade, que ia tendo suas funções, até então predominantemente residenciais, substituídas. A população de alta renda, que até os anos quarenta ali se concentrava, passou a ocupar outros espaços; já a população de baixa renda ocupou as velhas edificações e fez crescer a demanda por novas áreas residenciais, forçando a expansão da periferia urbana, então representada pelos fundos de vale não drenados e por outras áreas não urbanizadas, particularmente nas encostas (Carvalho; Pereira, 2006, p. 85-86).

Entre 1940 e 1950, mais da metade dos domicílios (58,3\%) destinava-se à locação. Pequenos comerciantes investiam o lucro excedente de seus negócios na produção de imóveis de aluguel, com o intuito de obter uma renda fundiária.

No censo de 1960, a porcentagem de domicílios destinados à locação recua para 52,4\%, reflexo da lei de inquilinato, que previa o congelamento dos preços de aluguéis. Essa legislação foi implantada pelo governo nacional em meados dos anos de 1940 e, além do congelamento de preços, coibiu o despejo sem causa justa. Essa regulamentação afetou diretamente os pequenos empreendedores, que deixaram de investir na produção de imóveis de aluguel (Bonduki, 1999). Como consequência, tal regulamentação contribuiu para consolidar um padrão periférico de ocupação do solo, marcado pelo espraiamento da cidade através de loteamento irregulares, sem a mínima estrutura. Nessa década, cerca de 14.000 casas foram construídas em Salvador, particularmente em áreas precárias, com pouco ou nenhum valor para o mercado fundiário.

Entre 1960 e 1970, a população do município cresceu $56 \%$, passando de 655.735 para 1.027.142 habitantes. Considerando que esse incremento se deu, principalmente, nos extratos de baixa renda, agravaram-se os problemas de moradia. Podemos dizer que, nesse período, a cidade vivenciou um processo de urbanização excludente. Conforme Carvalho e Pereira, a realização de grandes obras, no período, "acompanharam e anteciparam os vetores de expansão urbana e uma ocupação informal de famílias de baixa renda na periferia" (Carvalho; Pereira, 2006, p.86).

Observa-se, nessa fase, o crescimento do capital imobiliário, que se apropriou de áreas públicas de forma consentida e em conluio com o poder público municipal (Brandão, 1981).

Deacordo com Carvalho ePereira (2006, p. 86),

[...] [a] Prefeitura de Salvador, que detinha a maioria das terras do município, transferiu sua propriedade para (algumas poucas) mãos privadas, através da Lei da Reforma Urbana, em 1968. A abertura das avenidas de vale extirpou do tecido urbano mais valorizado um conjunto significativo de assentamentos de população pobre, que ocupavam tradicionalmente os fundos até então inacessíveis dos numerosos vales de Salvador. Além disso, o governo municipal erradicou invasões populares localizadas na orla marítima. 
No campo da produção para as famílias de rendimentos mais baixos, a estratégia do Estado da Bahia se concentrou na criação de uma empresa de economia mista, a Habitação e Urbanização da Bahia S.A (Urbis, 1965-1987) e o Instituto de Orientação às Cooperativas (Inocoop, 1969-1994), empresas públicas que, durante o seu período de atuação, construíram em torno de 3.069 habitações/ano, cifra insuficiente para atender à demanda. A Urbis foi criada durante o Governo Militar, em 4 de janeiro de 1965, pela Lei Estadual $n^{\circ} 2.114$, com o principal objetivo de operacionalizar a política habitacional do Governo do Estado. Atuou na construção de conjuntos habitacionais voltados para famílias com renda de até três salários mínimos, sendo responsável por 93\% da produção de moradias em todo o Estado da Bahia (SEHAB, 2007).

A maior parte dos conjuntos construídos pelo Estado em Salvador, nessa época, localizava-se no centro do município, na área conhecida como Miolo da cidade, desabitada até a década de 1960. Na região do Miolo, concentrou-se $66 \%$ da produção dos órgãos Urbis e Inocoop. O município concentrou suas atividades implantando lotes e loteamentos populares no Subúrbio (53\%) e, em segundo lugar, no "Miolo" (41,3\%) (Carvalho; Pereira, 2006).

Conforme destacam Soares e Espinheira (2006), a alternativa que o Estado encontrou para atender ao aumento da demanda por moradia, caracterizado por um crescimento urbano desenfreado, foi a construção de conjuntos habitacionais a partir do final dos anos de 1960.

Em 1970, a porcentagem de domicílios locados chega a $38,6 \%$, e a $34,8 \%$ em 1980 . Essa diminuição, provavelmente, relaciona-se com a implantação de programas habitacionais e com o crescimento das ocupações irregulares. Isso acontece, porque, de acordo com Gordilho-Souza, entre 1960 e 1980, houve uma consolidação do mercado imobiliário, sobretudo no que se refere à produção habitacional, que se deu através dos financiamentos promovidos pelo $\mathrm{BNH} / \mathrm{SFH}$ e que visavam a

... [promover] a construção e a aquisição da casa própria, especialmente para as classes de menor renda, que foram responsáveis por uma ampla produção do parque imobiliário e da infraestrutura urbana; apenas pela URBIS, na RMS - Região Metropolitana de Salvador foram produzidas em torno de 45 mil unidades habitacionais, até meados dos anos oitenta (Gordilho-Souza, 2002, p. 70).

De acordo com essa lógica, os conjuntos habitacionais contribuíram para a expansão das fronteiras urbanas de Salvador,

...[ao] se implantarem em áreas distantes dos espaços de ocupação consolidada, para as quais tiveram que ser estendidas as redes de infraestrutura e os serviços do município, beneficiando dessa maneira também grande quantidade de vazios urbanos criados pela descontinuidade da ocupação do solo (GordilhoSouza, 2002, p. 170).

Os conjuntos habitacionais produzidos nesse período correspondem a 10,88\% das formas de habitação IBGE (2000), majoritariamente de baixa renda. Esse modelo de produção do espaço urbano se apoiou na política habitacional nacional adotada a partir de 1964, com a criação Banco Nacional de Habitação (BNH), que teve seu auge na década de 1970. A lei federal de parcelamento do solo (6766/75) estabeleceu regras mínimas para a ocupação do solo, a definição de lote mínimo e o provimento de infraestrutura necessária para a instalação de loteamentos. Foi criada com o intuito de regular o uso do solo, coibindo o processo de expansão periférica e chegando a penalizar o empreendedor. No entanto, essa legislação contribuiu para consolidar o padrão de ocupação irregular em nossas cidades.

Os anos de 1980, conhecidos como a década perdida do ponto de vista econômico, foram marcados pelo processo de redemocratização do país e fortalecimento dos movimentos sociais. Em 1986, com a extinção do Banco Nacional de Habitação, a política nacional de produção de provimento habitacional se fragmenta, os programas estaduais e municipais se enfraquecem, e, em seu lugar, surgem os programas locais e alternativos. Essa transição se aplica às intervenções em Salvador. A partir de então, inicia-se um processo de intervenções pontuais, destacando-se os programas de urbaniza- 
ção e regularização fundiária de favelas.

Entre 1970 e 1990, a expansão urbana de Salvador foi influenciada por novos eixos de expansão, visandoa interligar oaeroporto ao novo Centro Administrativo da Bahia eà Estação Rodoviária. A instalação do ShoppingIguatemicriou umanovacentralidadeea"abertura de novas avenidas que se tornaram fatores decisivos para o surgimento de conjuntos habitacionais e a ocupação de espaços, até entãoeminentementerurais", distantes do centro da cidade, marcando a nova estruturação do espaço da cidade (Villagra; Oliveira, 2006, p. 32).

Na década de 1990, vimos que a retomada de programas de provisão habitacional se deu a partir de 1995/96. Com a implantação da Secretaria Especial de Desenvolvimento Urbano da Presidência da República (Sepur), o Governo Federal voltou a atuar na produção habitacional com os programas de Carta deCrédito Associativa do Fundo de Garantia por Tempo de Serviços (FGTS) e PAR, para o extrato médio e o médio baixo. Através da Caixa Econômica Federal (CEF), foram implantados os programas Habitar Brasil ePróMoradia, que, na Bahia, receberam a denominação de Viver Melhor, reiniciando a atuação do governo do estado. A Urbis passa a atuar na urbanização de favelas e, em quatro anos, efetua melhorias em 40 comunidades, beneficiando 14.173 famílias.

Em função dessa retomada dos investimentos em habitação, a década de 1990-2000 é marcada pela redução drástica da porcentagem de domicílios alugados, que cai para 15,46\%. Além do exposto acima, a hiperinflação vivenciada nos anos 1990 e a instabilidade econômica influenciaram sobremaneira a configuração desse quadro.

\section{PROGRAMAS}

\section{HABITACIONAISEM} SALVADOR DE 1996 A 2006

O governo do Estado, entre 1995 e 2006, apoiado em programas federais, retomou os investimentos em habitaçãopara baixa renda, promovendo conjuntos habitacionais, ou requalificando e urbanizando assentamentos irregulares em áreas degradadas e ambientalmente frágeis. A seguir, apresenta-se um quadro-síntese dos principais programas habitacionais do governo do estado para Salvador.

A porcentagem de imóveis alugados cai sensivelmente em 1991. Acredita-se que esse arrefecimento se deve à produção em massa de grandes complexos habitacionais, como o de Cajazeiras, realizados pelo governo estadual na década de 1980. Essa década ficou marcada também pelas grandes ocupações de terra.

Desde 2007, a Secretaria Estadual de Desenvolvimento Urbano (Sedur) redefiniu sua atuação, criou o Programa Casa da Gente, com o objetivo de produzir moradias para população de baixa renda, preferencialmente atendendo à faixa de renda de zero a três salários mínimos. O programa "visa a proporcionar condições dignas de vida nas áreas urbanas e rurais do estado da Bahia através de ações de produção habitacional, urbanização de assentamentos precários, projetos especiais e regularização fundiária." Esses eixos se associam a ações de mediação de conflitos fundiários urbanos, de salvaguarda ambiental, cultural e socioeconômica e de assistência técnica. O programa é orientado pelas diretrizes da Política Estadual de Habitação de Interesse Social (PEHIS) (BAHIA, 2008).

Dentre as ações da Secretaria Municipal de Desenvolvimento, Habitação e Meio-Ambiente, destaca-se o programa de Desenvolvimento Institucional,

Quadro 1 - Programas Habitacionais do Governo do Estado da Bahia para o Município de Salvador entre 1995 e 2006

\begin{tabular}{|l|l|}
\hline Programas & \multicolumn{1}{c|}{ Síntese } \\
\hline Viver Melhor & $\begin{array}{l}\text { Lançado em 1995, com o objetivo de melhoria da qualidade } \\
\text { de vida, especialmente em assentamentos subnormais e favelas. } \\
\text { Parceria com o Governo Federal e recursos do Orçamento } \\
\text { Geral da União (OGU) - Habitar Brasil e o Governo Estadual }\end{array}$ \\
\hline $\begin{array}{l}\text { Habitacional } \\
\text { do Servidor } \\
\text { Público }\end{array}$ & $\begin{array}{l}\text { Lançado em 1997, com o objetivo de oferecer moradias } \\
\text { subsidiadas aos servidores públicos estaduais com mais de dois } \\
\text { anos de efetivados e renda familiar de até 12 SM's e que não } \\
\text { fossem proprietários de algum outro imóvel financiado pelo SFH }\end{array}$ \\
\hline $\begin{array}{l}\text { Infraestrutura } \\
\text { em conjuntos } \\
\text { habitacionais }\end{array}$ & $\begin{array}{l}\text { Lançado em 1997, vinculado ao Pró-Moradia (Resolução 211/96), } \\
\text { com o objetivo de reduzir a inadimplência, através da realização } \\
\text { de obras de conservação e infraestrutura, construção de } \\
\text { equipamentos comunitários e embelezamento, como forma de } \\
\text { valorizar esses conjuntos }\end{array}$ \\
\hline \multicolumn{2}{|l}{ Sedur (BA) }
\end{tabular}


Planejamento e Informações Habitacionais. Ele visa a capacitar os técnicos do município de Salvador no sentido de se apropriarem dos instrumentos de gestão e produção do espaço, de acordo com as diretrizes do Estatuto da Cidade, do Plano Diretor de Desenvolvimento Urbano (PDDU) e da Lei de Ordenamento do Uso e Ocupação do Solo (Louos). Com a finalidade de implantar uma política municipal de habitação, entre 2007 e 2008, o governo municipal desenvolveu um Plano Municipal de Habitação de Interesse Social (PMHIS), que objetivava utilizar recursos financeiros próprios ou em parceria com o governo estadual e o federal, bem como obter financiamentos de agências internacionais. Destaca-se, nesse período, um programa de assessoria técnica aos assentamentos precários, no sentido de melhorar as condições do habitat da população de baixa renda (Salvador, 2004).

Esse plano municipal se articula em torno do Sistema Nacional de Habitação de Interesse Social (SNHIS). Ao aderir ao sistema, o município se compromete a enviar ao poder legislativo o projeto de lei de criação de um Fundo e um Conselho Municipal de Habitação. As intervenções se orientam a partir das diretrizes pactuadas no Plano Municipal de Habitação de Interesse Social (PMHIS) de 2007.

A seguir, é apresentado um quadro dos diversos programas em curso no município de Salvador, por meio do qual é possível observar a diversidade de recursos e ações.

Quadro 2 - Programas Habitacionais em Salvador - 2011

\begin{tabular}{|c|c|c|}
\hline Recursos & Programa & Modalidade \\
\hline Governo Federal e Municipal & $\begin{array}{l}\text { Projetos prioritários de } \\
\text { Investimento (PPI) }\end{array}$ & $\begin{array}{l}\text { Estudos, planos e projetos de urbanização de } \\
\text { assentamentos precários }\end{array}$ \\
\hline \begin{tabular}{l|l} 
FNHIS (PAC 2) \\
Programa Minha Casa, Minha Vida
\end{tabular} & & $\begin{array}{l}\text { Urbanização de assentamentos } \\
\text { precários }\end{array}$ \\
\hline $\begin{array}{l}\text { Ministério da Integração } \\
\text { Nacional e Município }\end{array}$ & Provisão de moradia & $\begin{array}{l}\text { Construção de casas para os desabrigados da } \\
\text { chuva - Jardim Campo Verde }\end{array}$ \\
\hline Municipal e Estadual & & $\begin{array}{l}\text { Produção de } 60 \text { unidades } \\
\text { habitacionais na Vila Preservação }\end{array}$ \\
\hline $\begin{array}{l}\text { Fundação Nacional de Saúde - } \\
\text { Funasa Emenda Parlamentar e } \\
\text { recursos do Município }\end{array}$ & Melhorias habitacionais & $\begin{array}{l}\text { Construção de } 130 \text { unidades sanitárias na } \\
\text { localidade de Nova Constituinte }\end{array}$ \\
\hline $\begin{array}{l}\text { Ministério das Cidades } \\
\text { FNHIS/PAC } 2 \text { e Município }\end{array}$ & Urbanização integrada & $\begin{array}{l}\text { Obras de saneamento básico, contenção de } \\
\text { encostas, construção de equipamentos } \\
\text { comunitários produção de unidades } \\
\text { habitacionais para relocação de famílias }\end{array}$ \\
\hline $\begin{array}{l}\text { Ministério das Cidades: } \\
\text { FNHIS e do Município }\end{array}$ & Urbanização integrada & Urbanização integrada \\
\hline Tesouro municipal - custeio & $\begin{array}{l}\text { Regularização urbanística } \\
\text { e fundiária }\end{array}$ & $\begin{array}{l}\text { De áreas públicas municipais mediante a } \\
\text { outorga da Concessão de Uso Especial para } \\
\text { Fins de Moradia (Cuem) e da Concessão de } \\
\text { Direito Real de Uso (CDRU) }\end{array}$ \\
\hline $\begin{array}{l}\text { Aliança de Cidades / } \\
\text { Banco Mundial }\end{array}$ & $\begin{array}{l}\text { Regulamentação das Zeis } \\
\text { de Salvador }\end{array}$ & \\
\hline Programa Habitar Brasil / BID & Plano de bairro & \\
\hline $\begin{array}{l}\text { Aliança de Cidades / } \\
\text { Banco Mundial }\end{array}$ & $\begin{array}{l}\text { Regulamentação das Zeis } \\
\text { de Salvador }\end{array}$ & $\begin{array}{l}\text { Planos de Regularização para quatro ZEIS } \\
\text { ocupadas (São Marcos, Pau da Lima, Centro } \\
\text { Histórico }-7^{\text {a }} \text { Etapa, Mata Escura/Calabetão) }\end{array}$ \\
\hline Programa Habitar Brasil / BID & & $\begin{array}{l}\text { Atualização do levantamento e mapeamento } \\
\text { dos vazios urbanos }\end{array}$ \\
\hline Programa Habitar Brasil / BID & & $\begin{array}{l}\text { Levantamento da situação fundiária das Zonas } \\
\text { Especiais de Interesse Social - ZEIS }\end{array}$ \\
\hline Municipal & $\begin{array}{c}\text { Planejamento e } \\
\text { fortalecimento institucional }\end{array}$ & $\begin{array}{l}\text { Prestação de serviço de assistência técnica em } \\
\text { arquitetura para famílias de baixa renda }\end{array}$ \\
\hline
\end{tabular}




\section{PLANO MUNICIPAL DE HABITAÇÃO DE INTERESSE SOCIAL DE SALVADOR (PMHIS)}

O Plano Municipal de Habitação de Interesse Social (PMHIS) se organiza de acordo com o mesmo recorte temporal proposto pelo Plano Nacional de Habitação, estabelecendo metas em médio e longo prazo. O PMHIS estima o déficit por faixa de renda, estabelecendo, como critérios, a demanda demográfica e relativa à relocação de obra de urbanização em área de risco e unidades obsoletas. Esse plano indica os valores a serem investidos e aponta as prováveis fontes de recursos, conforme a Tabela 2.

O universo dos domicílios alugados perfaz 19,5\%, um total de 168.909 (IBGE, 2010). Apenas uma parte desses domicílios é destinada a famílias de baixa renda. O município se caracteriza por seu potencial turístico, e uma parte do estoque de locação se destina a atender a essa demanda - turistas, operadores de turismo, brasileiros e estrangeiros que buscam se estabelecer na cidade. Existe, também, um submercado destinado a atender a estudantes do interior do estado que frequentam universidades: federal e estadual.

Os casarões-cortiços da área central, os cortiços em bairros populares e os imóveis em favelas de novas habitacões

Fonte: SEHAB, 2008

${ }^{1}$ Famílias conviventes, cômodos, domicílios rústicos e improvisados básico de 81.429

\section{LOCAÇÃO SOCIAL, ALGUMAS CONSIDERA- ÇÕES}

Garantir o acesso à moradia digna não significa, necessariamente, prover a demanda de habitação com o instituto da propriedade privada. Poderíamos ter outras formas que atendessem a famílias com necessidades muito específicas:

- Localização em áreas centrais e bem situadas, com acesso a serviços, onde se encontram as oportunidades de trabalho. Essas vantagens locacionais e a escassez de imóveis encarecem o preço do solo nessas áreas, inviabilizando o acesso dos mais pobres à propriedade, e, consequentemente, a permanência de moradores de baixa renda nessas localidades.

- Mobilidade das famílias que, em função de suas atividades, não conseguem se estabelecer no local para o qual foram deslocadas. A propriedade fundiária da terra fixa a população pobre em determinados lugares, geralmente distantes do centro, do local de trabalho e (ou) estudo, dos serviços e das oportunidades, confinando-a em conjuntos habitacionais construídos na periferia, afastados das benesses da cidade, além de limitar os deslocamentos por motivos econômicos e familiares.

- Situação financeira das famílias com baixo ou nenhum rendimento e sem estrutura suficiente para assumir a responsabilidade da proprieda-

Tabela 2 - Município de Salvador. Déficit habitacional acumulado, demanda demográfica por habitação até 2025 e necessidade de relocação por urbanização de assentamento, fontes de recursos para financiamento

\begin{tabular}{|c|c|c|c|c|c|c|}
\hline & $\begin{array}{c}\text { Déficit } \\
\text { acumulado }\end{array}$ & $\begin{array}{c}\text { Demanda } \\
\text { demográfica }\end{array}$ & $\begin{array}{c}\text { Relocação para obra } \\
\text { deurbanização, } \\
\text { área risco }\end{array}$ & $\begin{array}{l}\text { Unidades } \\
\text { obsoletas }\end{array}$ & Total & $\begin{array}{c}\text { Fontes de } \\
\text { recursos }\end{array}$ \\
\hline Até 2 SM & 50.821 & 95.464 & 13.561 & A calcular & 159.846 & $\begin{array}{l}\text { SNHIS (União/ } \\
\text { Estado/Município) }\end{array}$ \\
\hline De 2 a 3 SM & 17.800 & 41.325 & 5.811 & & 64.936 & $\begin{array}{l}\text { Mix FGTS/ } \\
\text { Subsídio }\end{array}$ \\
\hline De 3 a 5 SM & 6.758 & 43.975 & & & 50.733 & FGTS \\
\hline+ de $5 \mathrm{SM}$ & 6.011 & 76.550 & & & 82.561 & $\begin{array}{l}\text { SBPE/ SFI/ } \\
\text { Mercado }\end{array}$ \\
\hline Total & $81.390^{2}$ & 257.314 & 19.372 & & 358.076 & \\
\hline
\end{tabular}

O total do déficit urbano de 81.390 unidades habitacionais, somado ao déficit rural em Salvador, que é de39 unidades, resulta no déficit habitacional 
de privada. Tais famílias se tornam um problema para o sistema, pois, ao serem afastadas das atividades que lhes proporcionam alguma renda, transferem o imóvel e retornam à área de origem, consolidando um círculo vicioso.

No contexto definido acima, cabe refletir sobre a eficácia dos programas e das políticas habitacionais baseadas na "ideologia da casa própria”, ou na propriedade particular do imóvel. Para Rolnik (2010), em entrevista ao portal G1,

[...] é preciso discutir novas soluções que não sejam, necessariamente, o incentivo à propriedade privada por meio dos programas sociais. A propriedade e a construção da casa própria deveriam ser uma modalidade dos programas de provisão habitacional e não deveriam orientar a totalidade da produção. De acordo com ela, "[...] um dos elementos fundamentais, que hoje bloqueiam o acesso à moradia adequada para os mais pobres, é a mercantilização e a financeirização da moradia. A casa, em vez de um bem social fundamental, se transformou numa mercadoria”.

Whitaker (2011), em matéria do jornal Estado de São Paulo, afirma que a locação social deve ser vista como uma alternativa para o problema da habitação, mas que não exclui outras soluções. "A locação social é um modelo que não se aplicou porque no Brasil do regime militar se alimentou do sonho da casa própria, impulsionado pelas empreiteiras e pelo milagre econômico."

Para Morado e Parrela (2011, p. 10)

Do ponto de vista da população pobre, uma questão fundamental relativa à habitação nas condições atuais aqui se coloca: a casa própria seria de fato a forma mais adequada de provimento de moradia para este contingente populacional? Em um importante e pioneiro estudo sobre políticas habitacionais brasileiras, escrito em finais dos anos 70, Gabriel Bolaffi já observava que o aluguel, além de menos oneroso, seria mais adequado para grande parcela da população, sujeita a processos diversos de mobilidade. A oferta de apenas uma entre várias alternativas de provisão de moradia para esta parcela da população significa, além do mais, retirar das pessoas o poder de escolha, decisão e liberdade, pressuposto do exercício da cidadania.

Nesse sentido, o Programa Minha Casa, Minha Vida não difere dos programas e das políticas habitacionais adotadas desde meados do século XX, que se apoiam no sonho da casa própria. De acordo com Marli Carrara, liderança do movimento de moradia, em entrevista realizada pelo autor em 15 de agosto de 2012, o programa, apesar de sua importância, não foi capaz de atender às necessidades da demanda. Ela conta o caso do Sr. Manuel:

[...] quando a Sra for (lá na reunião) no conselho, a $\mathrm{Sr}^{\mathrm{a}}$ tem que dizer que o Minha Casa, Minha Vida tinha que se mudar! [As pessoas] vão deixar as casas para ir para o interior. Elas querem voltar para suas origens, porque a vida aos poucos está melhorando e elas querem voltar para casa, e elas tem que ter o direito [por exemplo] de chegar em [sua cidade] e ter o direito da casa delas lá! Porque se ela foi classificada, se ela foi selecionada, porque ela não pode transferir esse direito?

Isso seria possível se houvesse um cadastro único da demanda, e a produção de habitação acontecesse de forma descentralizada, atendendo a várias localidades. Mascia (2012), em sua dissertação, observa que, com o programa Minha Casa, Minha Vida na Bahia, houve uma descentralização territorial, embora as decisões continuassem concentradas na Caixa Econômica Federal (CEF).

De certa forma, os programas de arrendamento, como o PAR, ou de locação social poderiam se apresentar como alternativa a essa demanda que necessita se deslocar. Esses programas poderiam utilizar o passivo construído, não utilizado, existente principalmente em áreas centrais, reformar e reconverter o seu uso, quando necessário. Poderiam produzir novas unidades em conjuntos de uso misto: residencial (propriedade privada e locação), além de comércio e serviços.

No entanto, será que o Estado estaria preparado para gerir programas dessa natureza? Para Eleonora Mascia (2012), Superintendente de Habitação do Governo do Estado da Bahia, atualmente, ele não estaria preparado para exercer essa função. Segundo ela, há deficiência, pois, hoje, o Estado não possui estrutura necessária para gerenciar qualquer programa semelhante ao PAR, pois ele

... [se] demonstrou insustentável, na medida em que Caixa não tinha capacidade de dar manu- 
tenção a esses imóveis por longos períodos. Tanto que, em 2007, eles [a CEF abriu a possibilidade] de aquisição antecipada, para que os arrendatários tivessem preferência para adquirirem (os imóveis), antes dos 15 anos, (oferecendo) descontos (Entrevista realizada pelo autor em agosto de 2012).

\section{Marli Carrara (2012) também tem preocupa-} ções em relação à gestão de um empreendimento com fins de locação social. De acordo com ela:

Acho que o maior entrave é essa questão da gestão, a gente não consegue entender como é, e quem vai gerir um equipamento que é construído pelo estado, que mora gente, pessoas físicas, famílias, quem é que mantém aquilo? Quem que reforma? Quem é que gere? Para mim, é muito confuso imaginar um negócio deste (Entrevista realizada pelo autor em agosto de 2012).

Esse é um ponto bem complexo, pois existem outras questões, como o oferecimento de garantias de acesso e permanência da população, os recursos para a manutenção dos imóveis e a mediação de conflitos oriundos da convivência entre as

Quadro 3 - Programas de locação ou arrendamento

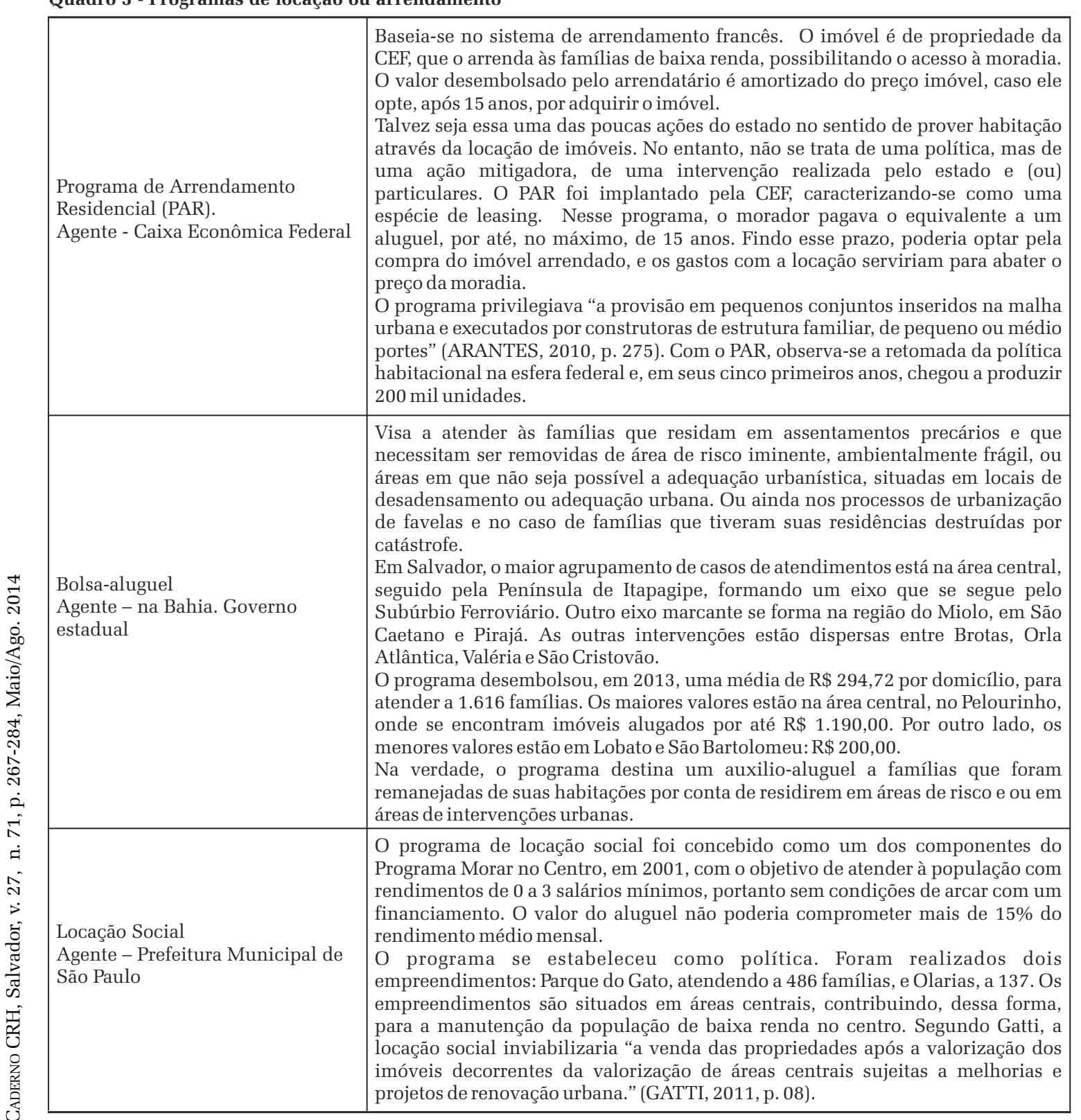

Sistematizado pelo autor em 2013. 
famílias. Seria necessário criar toda uma estrutura para atender a essa nova política. Para Marli, seria necessária a criação de uma política de Estado.

Destacamos, no Quadro 3, alguns programas, em três escalas de governo. Um é federal, o PAR, que, na verdade, não é um programa de locação, mas um programa de arrendamento. É importante destacar, quanto a esse programa, que ele rompe com a ideologia da casa própria. Há o Programa Bolsa-aluguel, implantado na esfera estadual, pelo governo da Bahia, que visa a dar suporte, por meio da locação ou de um auxilio para esse fim, a populações deslocadas por motivo de risco iminente ou de intervenções do poder público. Por último, destacamos, na esfera municipal, no município de São Paulo, o subprograma de locação social desenvolvido dentro do Programa Morar no Centro.

\section{PROGRAMA BOLSA-ALUGUEL EM SALVADOR}

O programa é gerido pelo Governo do Estado, através da Companhia de Desenvolvimento
Urbano do Estado da Bahia (CONDER). Atualmente, atende a 1.616 famílias, concentrando sua atuação nos subdistritos do centro antigo, no subúrbio e no miolo, conforme se verifica no mapa a seguir. O valor mensal investido é de R\$ 476.270,20, em média, R\$ 294,00 por família, embora predominem valores que variam de $\mathrm{R} \$$ 200,00 a R\$250,00. Na área do Centro antigo, destacamos o desembolso mensal de $\mathrm{R} \$ 40.460,00$, para atender a 34 famílias, o que significa um investimento mensal de $\mathrm{R} \$ 1.190,00$ por domicilio.

\section{O MERCADO DE LOCAÇÃO EM SALVADOR}

\section{Perfil atual do inquilino no município de Sal- vador}

Essa caracterização se apoiou no relatório que Pasternak e D’Ottaviano realizaram em 2012 para o Banco Mundial, a partir de dados do censo de 2010. Em relação ao tipo de casa e à infraestrutura, podemos afirmar que, em geral, as

Mapa 1 - Distribuição das comunidades atendidas pela Conder com a bolsa-aluguel, na cidade de Salvador

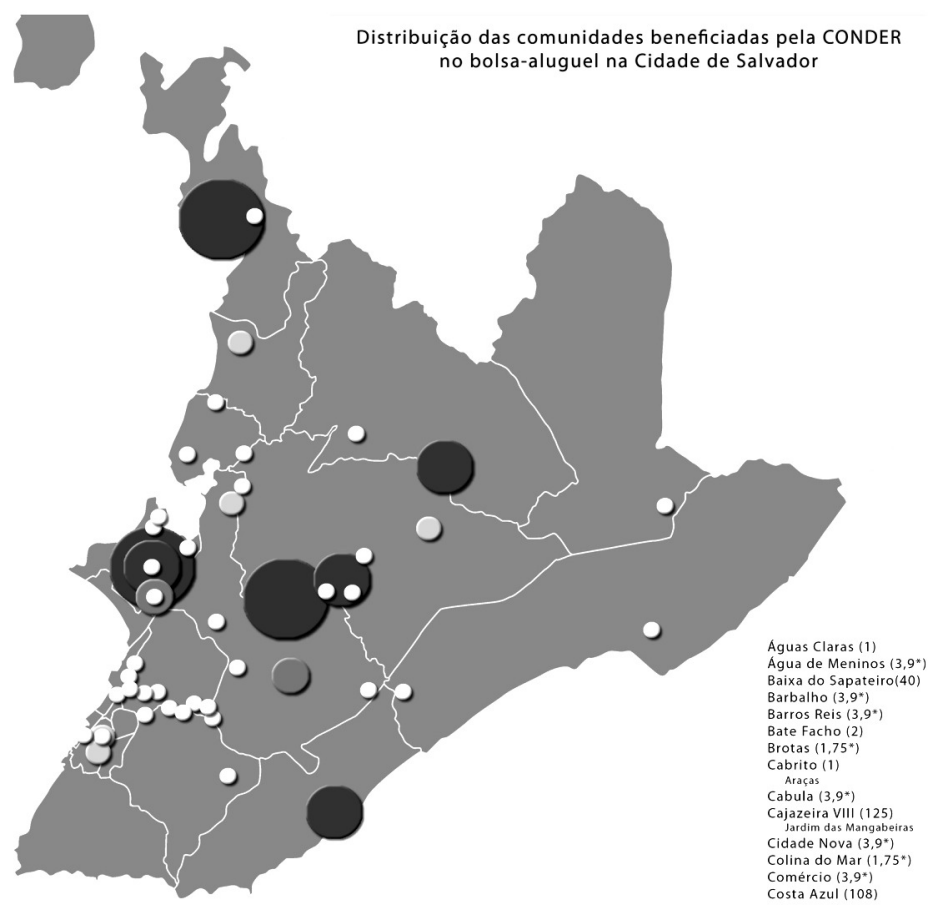

Número de Famílias

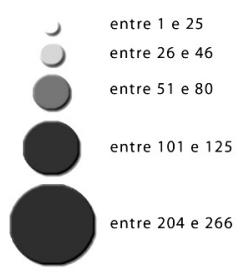

Fonte: Companhia de Desenvolvimento Urbano do Estado da Bahia - Conder/2012 Elaborado pelo autor em 2013 
habitações de aluguel apresentam condições de moradia um pouco mais precárias que as residências próprias. Isso porque $95 \%$ das moradias de aluguel são de alvenaria, com revestimento, enquanto, entre as próprias, essa porcentagem é de $98 \%$. O domicílio de aluguel tem menos cômodos e dormitórios que o próprio, sendo que, em média, possui 4,95 cômodos e 1,97 dormitórios, enquanto que a casa própria tem 5,72 cômodos e 1,66 dormitórios (Pasternak; D’Ottaviano, 2012).

Quase a totalidade (99,5\%) dos domicílios alugados é servida pela rede pública de água. Para Pasternak e D'Ottaviano (2012), isso acontece porque uma grande parte dos domicílios próprios permanentes é construída em terrenos invadidos: dos 860.410 domicílios do município de Salvador, 275.593 se distribuem entre os seus 241 aglomerados subnormais, ou seja, $32 \%$ dos domicílios municipais localizam-se em favelas, abrigando $33 \%$ da população do município. Diante disso, podemos dizer que essa configuração espacial pode ser o elemento de diferenciação entre os domicílios próprios e alugados (2012, p. 71).

Nos domicílios alugados, homens constituem a maioria dos chefes de família (56\%), enquanto que, nos domicílios próprios, essa percentagem é de $54 \%$. Os locatários possuem, em média, 40 anos de idade, são mais jovens que os proprietários, em média, sete anos.

Existe uma incidência de inquilinos oriundos de outras localidades, entre elas as cidades da região metropolitana de Salvador, do interior do estado da Bahia, de outros estados e de outros países. Os proprietários, em média, residem no município há mais tempo que os inquilinos, pois já se estabeleceram na cidade, consolidaram redes de trabalho, sociais, comunitárias, enquanto os locatários, por serem mais jovens, estão estabelecendo esses vínculos. A locação de uma residência pode se tornar o primeiro passo para sua fixação no município (Pasternak; D’Ottaviano, 2012).

O trabalho informal é a principal ocupação dos inquilinos, pois $76 \%$ se declararam envolvidos com essa atividade. Em média, a renda do chefe de família é maior entre os proprietários. Mais de $42 \%$ dos inquilinos fazem o deslocamento entre moradia e trabalho em até 30 minutos, provavelmente pelo fato de a região do centro antigo concentrar por volta de 50\% de imóveis de aluguel. Predominam, nessa região, as atividades informais, exercidas por uma população de baixa renda (2012).

Em síntese, Pasternak e D’Otaviano (2012, p.76) acrescentam que

[...] o perfil do inquilino de Salvador mostra que [ele] é alfabetizado, e cerca de $20 \%$ possui 12 anos e mais de escolaridade. Quase 74\% [dos domicílios] eram ocupados, sendo que as ocupações modais foram de trabalhadores do comércio e serviço (22\%), trabalhadores não especializados (14\%), liberais e intelectuais (13\%). A maioria dos inquilinos estava empregada no setor formal (62\%). A renda média dos locatários foi de 3,73 salários mínimos, para um aluguel médio de 0,76 salários mínimos. Quase 30\% trabalhavam no próprio domicílio, e, entre os que não trabalhavam em casa, $20 \%$ usavam mais de uma hora no deslocamento casa-trabalho.

\section{Localização e distribuição}

Nesta parte, utilizamos o conceito do IBGE para o censo, no qual Salvador é vista como distrito e suas regiões como subdistritos. Para essa leitura, organizamos os subdistritos de forma que o Centro seja composto por Sé, São Pedro, Santana, Santo Antônio, Pilar, Nazaré e Conceição da Praia, o Subúrbio Ferroviário por Penha, Passo, Mares, Plataforma, Periperi e Paripe, o Miolo por São Caetano, Pirajá, Valéria e São Cristóvão e a Orla Atlântica por Amaralina e Itapuã, Brotas e Vitória.

\section{Centro}

A maior proporção de domicílios alugados em relação a imóveis próprios se concentra na área central, correspondendo a mais de trinta por cento do total do Centro antigo, com destaque para a Sé, com 46,96\%, São Pedro, com 40,49\%, Passo, com $40,16 \%$, Nazaré, com $36,32 \%$ e Santana, com $34,61 \%$. Considerando que a região central congrega ainda os subdistritos de Santo Antônio, con- 
Mapa2 - Subdistritos de Salvador, domicílios alugados (\%)
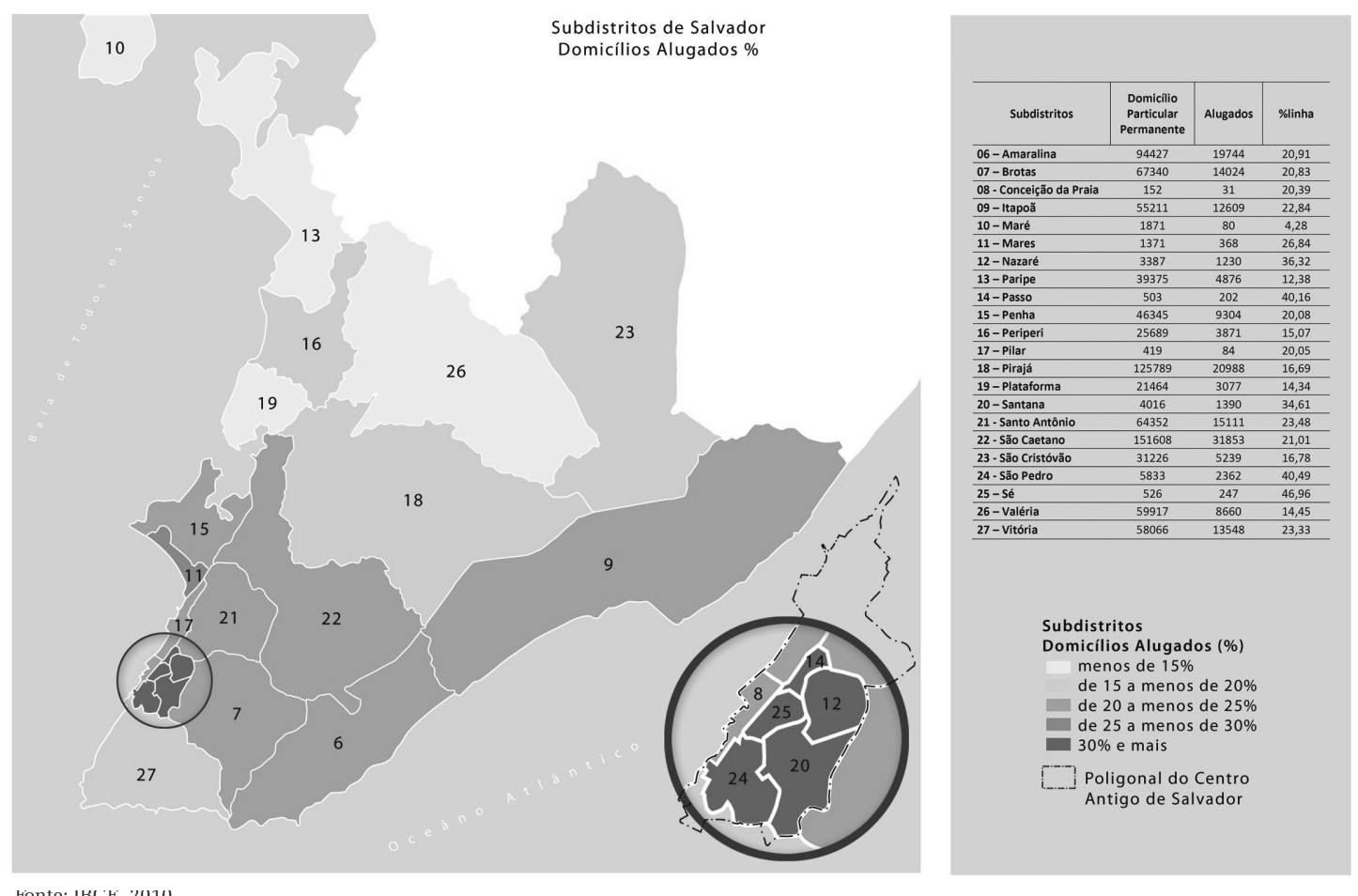

Fonte: IBGE, 2010

tíguo ao Pelourinho, Conceição da Praia e Pilar, ela é marcada pela ocupação por uma população de baixa renda, pois o rendimento de mais da metade das famílias varia de zero a um salário mínimo, com exceção dos subdistritos de São Pedro e Santana: o primeiro com 14,1\% de famílias com rendimentos acima de 5 salários mínimos e dessas, 3,2\% com mais de 10 salários; o segundo, Santana, com $10 \%$ das famílias com rendimentos acima de 5 salários mínimos.

\section{Península de Itapagipe}

Liga o bairro da Calçada, na Cidade Baixa (contígua à região central) ao Subúrbio ferroviário (região periférica). O subdistrito se caracteriza pela densidade baixa (46 hab./ha) e alta proporção de imóveis alugados (26,84\%). Em Mares, 3,7\% das famílias possuem renda mensal igual ou superior a 5 salários mínimos No subdistrito da Penha, predominam famílias com rendimentos que variam entre 0 e 1 salário mínimo (64,2\%). Nesse subdistrito, encontramos uma das maiores favelas de Salvador, a de Alagados.

\section{Subúrbio ferroviário}

O subdistrito do Subúrbio Ferroviário destaca-se pela alta concentração de pobres. Segundo o IBGE 2010, essa concentração apresenta os seguintes indicadores: 75,3\%, Periperi, 75,7\% e Paripe, $80,9 \%$. Abriga famílias com rendimentos que variam entre 0 e 1 salário mínimo. Os domicílios destinados à locação não ultrapassam a 15,07\% em Periperi. A densidade demográfica do Subúrbio Ferroviário é média baixa, conforme se pode verificar no Mapa 3.

\section{Miolo}

São Caetanoéum dos maiores subdistritos do município com $66,7 \%$ de famílias que recebem até 1 salário mínimo e com 21,01\% dos imóveis alugados. Nos subdistritos de Pirajá, Valéria e São Cristóvão, a maioria da população (em média, mais de 64\%) possui rendimento de 0 a 1 salário mínimo. 
Mapa 3 - Subdistritos de Salvador, densidade demográfica - 2010

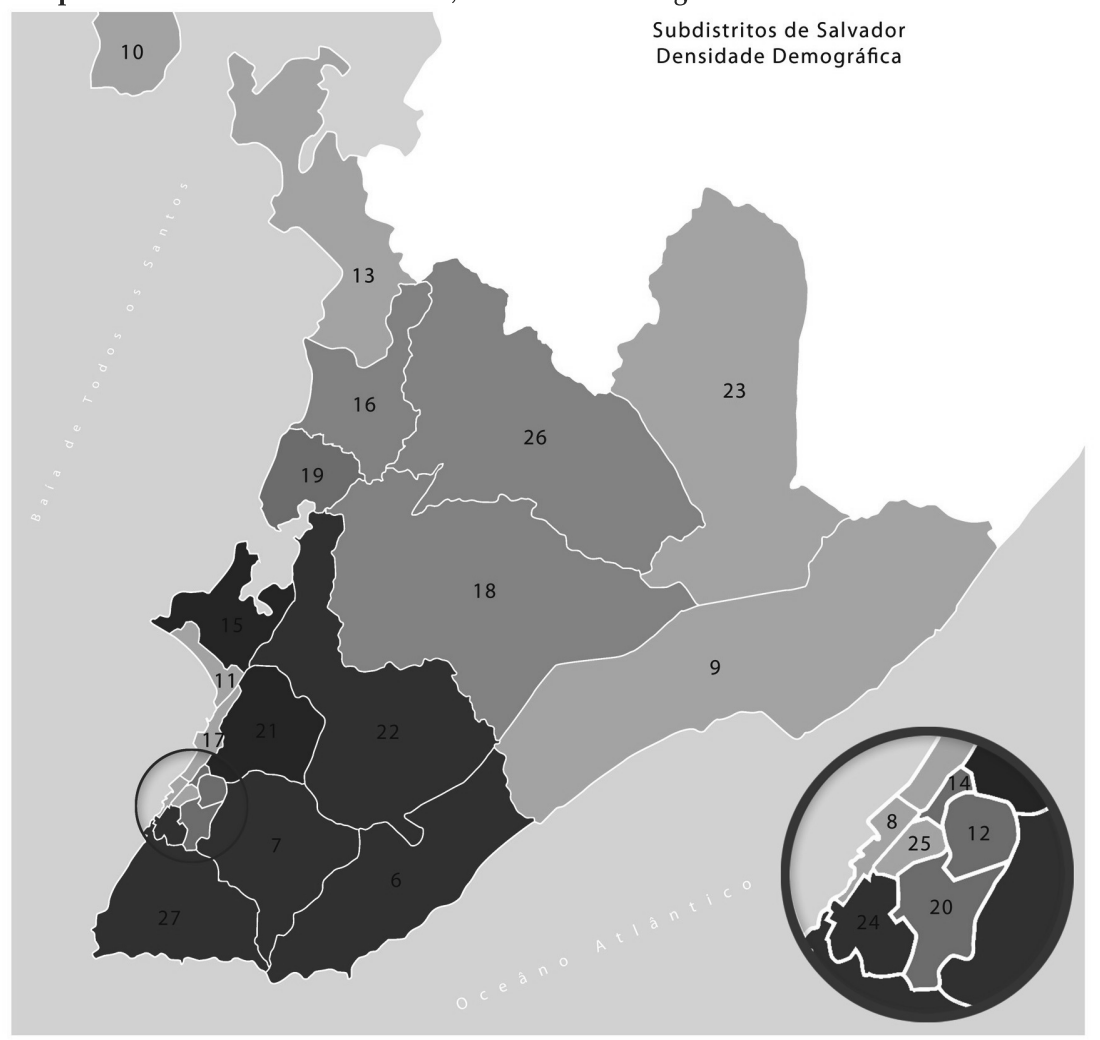

Fonte: IBGE, 2010
Subdistritos de Salvador 292740805

6 - Amaralina

7 - Brotas

8 - Conceição da Praia

9 - Itapuã

10 - Maré

11 - Mares

12 - Nazaré

13 - Paripe

14 - Passo

15 - Penha

16 - Periperi

17 - Pilar

18 - Pirajá

19 - Plataforma

21 - Santo Antônio

22 - São Caetano

23 - São Cristóvão

24 - São Pedro

25 - Sé

26 - Valéria

\section{Orla Atlântica - Amaralina e Itapuã}

O subdistrito de Amaralina é composto peoeste do município, na orla marítima, apresentando baixa densidade de ocupação (45hab/ha). Agrega uma boa parte dos "condomínios" e loteamentos das classes média e alta. Ainda que 3,9\% das famílias tenham um rendimento superior a 10 salários mínimos, 19,6\% percebem de 3 a 10 salários mínimos. Do total dos domicílios, 22,84\% estavam alugados.

\section{Brotas}

Brotas se caracteriza por um ser um subdistrito que abriga uma população das classes média e média alta, com 9,1\% de famílias com rendimentos entre 5 a 10 e 3,6\% acima de 10 salários mínimos. Com uma média de 194 hab./ha, possui 20,83\% dos domicílios destinados à locação.

\section{Vitória}

O subdistrito de Vitória é formado pelos 


\section{CONSIDERAÇÕES FINAIS}

A partir dos anos de 1960, as grandes cidades começam a atrair um contingente de migrantes, gente do campo que busca oportunidades. Muitos, sem condições de pagar um aluguel, começam a ocupar a cidade de forma irregular. Diante dessa realidade, o Estado inicia os programas habitacionais, o que teve seu auge com o Banco Nacional de Habitação (BNH). Esses programas visavam a atender ao trabalhador empregado com rendimentos de acima de 3 salários mínimos. As cidades começam a crescer, expandindo seu perímetro urbano, para atender à demanda de loteamentos, regulares. Concretizava-se a garantia de permanecer na cidade pela propriedade privada (o lote), seguida da construção (inacabável) da casa, o que consumia força e renda do trabalhador.

A locação social quase nunca foi pensada como alternativa de política pública, pois, talvez, o que se começou a denominar de discurso da casa própria tenha incutido, na população, a ideia de que a propriedade privada seja uma simbologia de progresso individual, de ter vencido na cidade.

O PAR inovou, pois trabalhou com a ideia de arrendamento com opção de compra após 15 anos, amortizando o valor gasto pelo usuário durante o período. Verificou-se a falta de estrutura da grandes e médias cidades. Em Salvador, 20\% dos imóveis residenciais ocupados eram destinados à locação. Nos subdistritos que agregam bairros de menor rendimento, mais de $70 \%$ dos domicílios contam com ganhos familiares que variam de 0 a 1 salário mínimo. Neles, a percentagem de imóveis alugados em relação aos próprios permanentes é menor que $16,78 \%$. Nesses locais, possuir um imóvel, ainda que irregular, configura-se como uma estratégia de sobrevivência dos mais pobres, significando uma redução dos custos, já que isso não onera sua renda com o gasto de aluguel.

Os subdistritos da região central apresentam uma alta proporção de imóveis alugados. Nessa área, concentra-se, de forma significativa, uma população cujos rendimentos familiares são muito baixos, que aluga cômodos em imóveis precários, tombados pela UNESCO como patrimônio da humanidade. O projeto de renovação do centro histórico vem, sistematicamente, expulsando a população pobre para fora da área. Mas ela resiste às investidas do Estado e do mercado, ocupando imóveis vazios, ou acionando o Ministério Público, no sentido de exercer o direito de permanecer no centro. Muitas famílias estruturam suas vidas em função das facilidades de deslocamento - trabalho, estudo, lazer - que os centros das cidades proporcionam.

Como vimos, os maiores valores desembolsados pelo Programa Bolsa-Aluguel estão na área central. Mourad (2011) destaca que o processo de valorização dos imóveis naquela área encarece os investimentos em habitação social. Um programa de locação social poderia equacionar o problema de manutenção das famílias de baixa renda que ali residem. A alta proporção de imóveis locados - provavelmente a famílias com um rendimento que varia entre zero e dois salários mínimos - serviria de justificativa para se implantar tal programa, pois, ao contrário do que acontece no subúrbio e no miolo, a população pobre não consegue adquirir seu imóvel.

Longe de representar a solução para os problemas gerados pela disputa por espaço na cidade, a locação social poderá se constituir num poderoso instrumento na batalha travada pelos movimentos sociais com os proprietários de terra e, muitas 
vezes, com o poder público, que não consideram, nas intervenções, o entorno social já estabelecido. São pessoas que lutam pelo direito à cidade, de permanecer no local e de preservar seus costumes e cultura. Lutam contra a gentrificação na renovação de áreas históricas, remoções injustificadas e falta de transparência nessas intervenções.

Recebido para publicação em 20 de dezembro de 2013 Aceito em 02 de março de 2014

\section{REFERÊNCIAS}

ARANTES, Pedro F. Pesquisa sobre o PAR apresenta antecedentes do "Minha Casa, Minha Vida". Revista Pós. São Paulo, v.17, n.28, dez. p.275-280, 2010.

ARAUJO, James Amorim. Modernização capitalista e reprodução da classe trabalhadora na periferia de Salvador/ $B A$ : o Pero Vaz as formas e práticas derivadas da escravidão. 2010. Tese (Doutorado em Geografia) - Faculdade Filosofia Letras Ciências Humanas, Universidade de São Paulo, 2010.

BAHIA, Governo do Estado da. Lei $\mathrm{n}^{\circ} 11.041$ de 07 de maio de 2008, que institui a Política e o Sistema Estadual de Habitação de Interesse Social e cria o Fundo Estadual de Interesse Social. Salvador.

BALTRUSIS, Nelson. A dinâmica do mercado imobiliário na RMSP: um estudo de caso nas favelas de Paraisópolis e nova Conquista. 2000. Dissertação (Mestrado Faculdade de Arquitetura e Urbanismo) - Pontifícia Universidade Católica de Campinas. São Paulo, 2000.

O mercado imobiliário em favelas e o processo de estruturação do espaço. 2005. Tese (Doutorado) - Faculdade de Arquitetura e Urbanismo da Universidade de São Paulo. 2005.

BONDUKI, Nabil. Origens da habitação social no Brasil. São Paulo: Estação Liberdade, 1999.

BRANDÃO, Maria D. de A. O último dia da criação: mercado, propriedade e uso do solo em Salvador. In VALLADARES, Lícia do P. (Org.). Habitação em questão. Rio de Janeiro: Zahar, 1981.

CARVALHO, I. M. M.; PEREIRA, G. C. Segregação sócioespacial e dinâmica metropolitana. In:

(Coord.). Como anda Salvador? Salvador: UFBA,' 2006.

GATTI, Simone. O projeto Nova Luz e o Programa de Cortiços no centro de Sã̃o Paulo entre processos de demolições, despejos e deslocamentos. 2011. Disponível em: <http:// lefthandrotation.com/museodesplazados/download/ ARTIGO SimoneGatti_2011.pdf>. Acesso em: ago. 2012.

GORDILHO-SOUZA, Angela. As cidades na cidade - aventuras do capital e do trabalho na produção do espaço de Salvador. In: CARVALHO, Inaiá; PEREIRA, Gilberto Corso (Org.) Quem faz Salvador. Salvador: Pró-Reitoria de Extensão da UFBA, 2002.

Limites do habitar: segregação e exclusão na configuração urbana contemporânea de Salvador e perspectiva no final do século XX. Salvador: Edufba, 2000.

IBGE. Instituto Brasileiro de Geografia Estatística. Censo Demográfico 2010 - Resultados Preliminares da Amostra. Disponível em: < http://www.ibge.gov.br/home/ estatistica/ populacao/ censo2010/resultados_preliminares_amostra/ notas_resultados_preliminares_amostra.pdf.>

Censo Demográfico. Série histórica 1940, 1950, 1960, 1970, 1980, 1991, 2000. Disponível em: dhttp:/ www.sidra.ibge.gov.br/bda/acervo/ acervo7.asp?z $=t \& o=3$.

KOWARICK, Lúcio. A espoliação urbana. Rio de Janeiro: Paz e Terra, 1979.

LAURIANO, Carolina. Aluguel social pode conter favelização, diz relatora da ONU. G1, Rio de Janeiro, 25 mar. 2010. Disponível em <http://g1.glorbo.com/noticias/rio/0, mul1542952-5606,00-aluguel+social + pode+ conter+favelizacao+diz+relatora +da + onu.html>. Acesso em: 30 dez. 2013.

MARICATO, Ermínia. Brasil, cidades: alternativas para a crise urbana. Petrópolis: Vozes, 2001.

MASCIA, Eleonora Lisboa. Habitação para além da metrópole. 2012. Dissertacão (Mestrado em Arquitetura e Urbanismo) - Faculdade de Arquitetura, Universidade Federal da Bahia. Salvador, 2012.

MORADO, Denise N.; PARRELA, Simone T. Programa Minha Casa Minha Vida: a (mesma) política habitacional no Brasil. Arquitextos, v.12, jun. 2011. Disponível em $<$ http://www.vitruvius.com.br/ revistas/read/arquitextos/ 12.133/3936 >. Acesso em: fev. 2013

MOURAD, Laila Nazem. O processo de gentrificação do Centro Antigo de Salvador (2000 a 2010). 2011. Tese (Doutorado em Arquitetura e Urbanismo) - Faculdade de Arquitetura e Urbanismo, Universidade Federal da Bahia. Salvador, 2011.

.Democratização do acesso terra urbana em Diadema. 2000. Dissertação (Mestrado em Urbanismo) Pontifícia Universidade Católica de Campinas. São Paulo, 2000.

ORENSTEIN, José. Problemas no Minha Casa, Minha Vida acendem alerta sobre necessidade de monitoramento, dizem urbanistas. O Estadão, Política. São Paulo, 21 jan. 2011. Disponível em: <http://www.estadao.com.br/noticias/nacional,problemas-no-minha-casa-minha-vida-acendem-alerta-sobre-necessidade-de-monitoramento-dizemurbanistas,669414,0.htm>. Acesso em: 30 dez. 2013.

PASTERNAK, Suzana; D’OTTAVIANO, Camila. (Org.) Relatório final: investigação sobre moradia de aluguel no Brasil. São Paulo: FAUUS̉P, 2012.

SALVADOR. Prefeitura Municipal de. Plano Diretor de Desenvolvimento Urbano - PDDU. Salvador, 2004.

SEDHAM. Secretaria Municipal de Desenvolvimento Urbano, Habitação e Meio Ambiente. Relatório de Gestão do Fundo Municipal de Habitação - FMH. Prefeitura Municipal de Salvador, mar. 2011.

Uso e Ocupação do Solo em Salvador. Cadernos da Cidade Prefeitura Municipal de Salvador, n.1, jun. 2009.

SEHAB . Secretaria Municipal de Habitação de Salvador. Plano Municipal de Habitação de Salvador 2008 -2025. Prefeitura Municipal de Salvador, mar. 2008.

Subsídios para elaboração do Plano $\mathrm{Mu}$ nicipal de Habitação de Salvador, Relatório 1 - Plano de Trabalho; Síntese de Documentos; Formato da Plenária - maio, 2007.

SOARES, Antonio Mateus de C.; ESPINHEIRA, Carlos Geraldo D’Andréa. Conjuntos habitacionais em Salvador - Ba e a transitória inserção social. Revista Risco, São Carlos, v.3, 2006. Disponível em <www.revistas.usp.br/risco/ article/download/44657/48277>. Acesso em: mar. 2013.

VILLAGRA, R. M. T. A.; OLIVEIRA, A. M. S. Elementos limitantes da oferta de habitação de interesse social na cidade do Salvador, Ba. Sitientibus, Feira de Santana, n.35, p.29-56, jul./dez. 2006. 


\section{HOUSING POLICY AND SOCIAL RENT IN SALVADOR, BRAZIL}

\author{
Nelson Baltrusis \\ Laila Nazem Mourad
}

This article seeks to analyze the real state rental market in Salvador, Brazil. Initially, we describe the housing problem in Salvador based on the guidelines and actions foreseen in the $\mathrm{Mu}$ nicipal Plan for Social Interest Housing (PMHIS). Then we treat the policies implemented by state and federal administrations, emphasizing the experience of Social Leasehold Housing (PAR), and including a few considerations on My Home, My Life program. We also approach the issue of the rental market in Salvador based on the profile of dwellers and on the dynamics of the market.

KEYwORDs: Social rent. Housing policy. Urban planning instruments.

\section{POLITIQUE DE L'HABITAT ET LOGEMENTS SOCIAUX À SALVADOR}

\author{
Nelson Baltrusis \\ Laila Nazem Mourad
}

L'objectif de cet article est d'analyser le marché de l'immobilier destiné à la location à Salvador. Dans un premier temps, et pour caractériser le problème du logement à Salvador, nous nous basons sur les directives et les actions prévues par le Plan Municipal des Logements Sociaux (PMHIS). Nous abordons ensuite les politiques mises en place par le gouvernement fédéral, mettons en évidence l'expérience du Programme de Bail Résidentiel (PAR) et nous y ajoutons quelques considérations concernant le Programme "Ma Maison, Ma Vie”. La question du marché locatif à Salvador est également traitée à partir du profil des habitants et de la dynamique du marché.

Mots-CLÉs: Location sociale. Politique de l'Habitat. Instruments de planification urbaine.

Nelson Baltrusis - Doutor em Arquitetura e Urbanismo. Professor adjunto do Programa de Pós-graduação em Planejamento Territorial da Universidade Católica do Salvador. Professor da Universidade Católica do Salvador. Pesquisador colaborador da Pontifícia Universidade Católica de São Paulo, Instituto de Estudos, Formação e Assessoria em Políticas Sociais. Foi consultor do processo de elaboração de planos diretores participativos no município de Jandira pela Fundação para o Desenvolvimento da UNESP, FUNDUNESP e nos de Guarulhos, Vitória e Mogi das Cruzes pelo Instituto Pólis. Tem experiência na área de Planejamento urbano, atua principalmente nos seguintes temas: planejamento urbano, favelas, instrumentos urbanisticos, economia urbana e mercado imobiliario. Publicações recentes: Política Nacional de Habitação hoje. Produção de mercado com recursos do SBPE como ação dominante. Arquitextos (São Paulo), v. 1, p. 1, 2013; Transformações do modo de morar na metrópoles contemporâneas. Novos discursos, velhos problemas. Caderno CRH (UFBA. Impresso), v. 23, p. 50-75, 2010; Ricos e pobres, cada qual em seu lugar? a desigualdade sócio-espacial na metropole paulistana. Caderno CRH (UFBA. Impresso), v. 22, p. 135-149, 2009.

Laila Nazem Mourad - Doutora em Arquitetura e Urbanismo. Bolsista de pós-doutorado PNPD-Capes. Membro do grupo de pesquisa Lugar Comum. Tem experiência na área de Arquitetura e Urbanismo, com ênfase em política urbana, planejamento urbano e regional, plano diretor, plano estadual e municipal de habitação de interesse social, plano de bairro e processos de reabilitação em centro histórico. Publicações recentes: Movimentos de resistência ao processo de renovação conservadora do Centro Histórico do Salvador. In: José Rios Fernandes; Lúcio Cunha; Pedro Chamusca. (Org.). Geografia \& Política, Políticas e Planeamento. 1ed.Porto: GEGOT, 2013, v. 1, p. 1-788; Centro Histórico: planejamento para o turismo. In: Centro Gaspar Garcia de Direitos Humanos. (Org.). Moradia é Central: Lutas, Desafios e estratégias. 1ed.São Paulo: Centro Gaspar Garcia de Direitos Humanos, 2012, v. 1, p. 60-63; Lutas pela conquista do direito à moradia no Centro Histórico de Salvador. In: Edésio Fernandes; Betânia Alfonsin. (Org.). Revisitando o instituto do tombamento. 01ed.Belo Horizonte: Fórum, 2010, p. 01-468. 